УДК 316.647 .5

DOI https://doi.org/10.32838/2709-3093/2021.5/04

Калмиков Г.В.

Університет імені Григорія Сковороди в Переяславі

\title{
Мисан I.B.
}

Університет Григорія Сковороди в Переяславі

Рудківська Н.Л.

Університет Григорія Сковороди в Переяславі

\section{ФУНКЦІОНАЛЬНО-ЗМІСТОВЕ ПОЛЕ ЗНАЧЕНЬ ФЕНОМЕНУ «ТОЛЕРАНТНІСТЬ»У ЛЮДИНОМІРНИХ НАУКАХ}

У статті розкриваються різні підходи до тлумачення толерантності, обгрунтовується потреба у розгляді функиіонально-змістового поля значень феномену толерантності, нових значень, пов'язаних з активним прийняттям людиною оточуючої реальності, з диферениійованим, але таким, що не суперечить нормам права, терпимим ставленням до Інших. Толерантність як наукова проблематика, світова стратегія і ключове поняття у питаннях миру актуалізується з огляду на ї̈ значення для сочіального життя у суспільствах.

У статті репрезентуються маловідомі думки авторитетних психологів щодо суті иієї наукової категорії; подаються наукові підходи до трактування толерантності і систематизації психологічних тлумачень толерантності.

В основному матеріалі статті представлені результати системного аналізу сучасних літературних джерел, зокрема зазначається необхідність осягнення смислів толерантності для трансформачії їі в иінність і норму взаємовідносин, що є передусім справою вчених.

Стаття також присвячена виокремленню різних аспектів у трактуванні толерантності: філософського, методологічного, етичного, суспільного, суспільно-політичного, соиіального, культурологічного, соціально-психологічного, соціально-перцептивного, психолого-педагогічного, професійного; психологічному розгляду толерантності як поведінки, здібності, властивості, свідомого рішення, відношення, риси характеру, моральної якості та багатьох інших значень.

Систематичний огляд і системний аналіз наукових джерел дав змогу констатувати відсутність єдиного підходу до експлікаиії иього феномену, яка б відображала його багатогранність, багатомірність $і$ багатовимірність. Проте в представлених визначеннях $і$ наявних у научі підходах до толерантності можна знайти певні спільні тендениії і закономірності, які виокремлюються під час аналізу трактовок иього явища.

Ключові слова: толерантність, психологічні значення, функиіонально-змістове поле, смисли.

Постановка проблеми. Поняття «толерантність» міцно увійшло в науковий обіг у психологічному значенні терпимості. Толерантність за різними визначеннями - це терпимість до: a) іншого світогляду, образу життя, характеру; б) інших звичаїв, звичок, поглядів, способів самовираження й прояву людської індивідуальності; в) іншої мови, культури, поведінки.

Вважається, що поняття «терпимість»є категоріальним для терміну «толерантність» [36]. Проте термін «терпимість», як синонім слова «толерантність», набув у сучасних умовах, як зазначає М.А. Семашко, нового значення, яке не пов'язане 3 пасивним прийняттям оточуючої реальності й непротивленням їй, із здібністю людини терпіти лише через милосердя або поблажливість, як це визначав В.І. Даль [37].

Наявні сьогодні різноваріантні, часом суперечливі підходи до тлумачення толерантності зумовлюють потребу вивчення феномену «толерантність» як загальнонаукової і конкретно-наукової - психологічної - категорії.

Ця проблематика актуалізується сьогодні не тільки з огляду на ії значущість для сучасної науки та соціального життя, а й тією світовою стратегією, в межах якої XXI століття оголошено століттям толерантності. Століття, яке отримало ім'я толерантності, знайде шанс, зазначає О.Г. Асмолов, стати дійсно століттям толерантності, взаєморозуміння несхожих один на одного людей, 
сприймання 3 повагою інших позицій і точок зору не тільки на сторінках наукових журналів, а й у душах людей [3].

Суть толерантності як «міжнародного терміну» й «ключового поняття в проблематиці миру» [5] сформульована в матеріалах конференції ЮНЕСКО (1995 р.) на тлі визнання єдності та багатоманітності людства, взаємозалежності всіх від кожного й кожного від усіх, поваги прав іншого, зокрема права бути інакшим, стриманості від заподіяння шкоди, оскільки такий вчинок, заподіяний іншому, означає шкоду для всіх і для самого себе.

Аналіз останніх досліджень та публікацій. Проблематиці толерантності присвячені дослідження багатьох вітчизняних і зарубіжних вчених, зокрема: О. Асмолова, В. Бойка, В. Лабунської, А. Леонтьева, А. Макарова, Т. Марголіної, П. Ніколсона, М. Семашко, Г. Солдатової, В. Тішкова, В. Шаліна та багатьох інших науковців, погляди яких репрезентуватимуться в основному змісті статті.

Попри широку представленість в психологічній науці різних підходів до визначення толерантності, функціонально-змістове поле значень феномену «толерантність» до цього часу залишається недостатньо вивченим. Відтак не існує загальновизнаного і загальноприйнятого розуміння цього важливого психологічного явища.

Постановка завдання. 3 урахуванням значущості розв'язання проблеми толерантності для вітчизняної та світової науки, а також гармонійного існування планетарного людства мета статті полягатиме в описі результатів систематичного міждисциплінарного огляду й системного аналізу сучасних літературних джерел з питань толерантності.

Завдання опису результатів теоретичного дослідження полягають у: а) репрезентації маловідомих сьогодні думок авторитетних психологів щодо суті цієї наукової категорії; б) поданні наукових підходів до трактування цього феномена й систематизації психологічних тлумачень толерантності.

Виклад основного матеріалу. Розглянемо, чим же насправді $\epsilon$ толерантність, враховуючи іншомовне походження цього слова й ті трансформації, що відбулися в розумінні його значення під впливом багатьох факторів: соціальних, політичних, релігійних, суспільних, етнічних, психологічних, економічних, культурних тощо.

Науковці, які здійснили глибокий психологічний аналіз проблеми толерантності, обгрунтовано стверджують, що уявлення про смисли толерантності не може вичерпуватися коротким нарисом. Осягнення іiі смислів 3 метою перетворення толерантності на цінність і норму стосунків у сучасному суспільстві, яку визнають усі народи Землі, - справа перш за все вчених та інших суспільних діячів [5].

Кожний 3 тих, хто звертається до аналізу поняття толерантності, розглядає його під певним кутом зору, висвітлюючи той чи інший аспект цієї проблеми. Тому одне із завдань, як наголошують О.Г. Асмолов, Г.У. Солдатова і Л.А. Шайгерева, це як можна ширше представити палітру смислів толерантності [там само].

Згідно 3 філософським енциклопедичним словником якість «толерантність» необхідна відносно до особливостей різних народів, націй i релігій. Вона $є$ показником впевненості в собі й усвідомлення надійності своїх власних позицій, ознакою відкритої для всіх ідейної течії, яка не боїться порівняння з іншими точками зору і не уникає духовної конкуренції [12].

У наукових джерелах зазначається, що психолінгвістичні експерименти над носіями мови засвідчили наявність загального ядра концептів «толерантність» $\mathrm{i}$ «терпимість», але разом показали й серйозні відмінності: вони належать до різних галузей діяльності й культури людини. Толерантність $€$ поняттям суспільно-політичної сфери, а терпимість - релігійної або духовної. Концепт терпимість, будучи одним із складових елементів концепту толерантність, передбачає більшу духовність, а толерантність більшою мірою виражає роботу розуму, а не душі [23].

Тлумачення слова «терпимість», використаного в значенні толерантності, несе в собі дещо інші смисли, пов'язані з активною соиіальною поведінкою, до якої людина приходить добровільно й свідомо [29]. Отже, терпимість - це прояв колективної та індивідуальної поведінки, яка полягає в непереслідуванні тих, чий образ думок або дій не співпадає з твоїм власним і викликає чиєсь несхвалення. Протилежністю терпимості $€$ прояв нетерпимості і фанатизму [13].

Інтолерантність грунтується на переконанні, що твоє оточення, твоя система поглядів, твій образ життя стоять вище від цінностей інших членів суспільства. Частіше це не просто відсутність відчуття солідарності, - це неприйняття іншого за те, що він виглядає, думає, діє по-іншому (іноді просто за те, що він існує). Така нетерпимість скоріше $\epsilon$ індивідуальним і колективним «комплексом переваги», який починається 3 неприйняття, відкидання, ігнорування й приниження інших форм образу життя та призводить до різних проявів реалізації цього комплексу, зокрема до геноциду. Нетерпимість є проявом бажання домінувати, придушувати, а не переконання [5]. 
«Толерантність» сьогодні, зауважує Л.В. Баєва, не означає покірного терпіння. Сьогодні вона передбачає значно більше - визнання інакомислення 3 позиції рівноправного й достойного вивчення. Здатність прощення як результат терпіння не означає бездіяльність і дозвіл насилля; так і толерантність не є звільнення від моралі, культури, норм права, це не поступка варварству, злочинності, дикунству тощо. Толерантність - оцінка людей за їх належністю до будь-якої групи або типу.

Толерантність полягає в наданні іншим права жити відповідно до власного світогляду, в повазі, прийнятті і правильному розумінні інших культур, образів життя і традицій. Толерантність не має нічого спільного як з байдужістю, поблажливістю, потуранням, так і з терпимістю до соціальної несправедливості. Вона не пов'язана з відмовою від своїх переконань або поступками чужим переконанням. Толерантність також не означає нав'язування своїх переконань іншим людям [1, с. 55].

Толерантність може існувати в реальному прояві тільки у тих випадках, коли людина пробує дивитися на ситуацію очима «іншого».

Г. Олпорт, вибудовуючи типологію особистості, спирається на опозицію термінів «толерантність» vs «інтолерантність». Він називає комплекс ознак, характерних для толерантної людини:

1) знання самого себе, оскільки толерантна людина завжди гарно обізнана про свої переваги і недоліки та не схильна в усіх бідах звинувачувати оточуючих;

2) захищеність - відчуття безпеки й переконаність, що із загрозою можна впоратися;

3) відповідальність - розвинене почуття самодостатності й соціальної зрілості, що не дозволяє перекладати відповідальність на інших;

4) потреба у визначеності - відсутність схильності ділити світ на чорне і біле та визнання багатоманітності, готовність вислухати будь-яку точку зору і відчути менший дискомфорт в стані невизначеності;

5) орієнтація на себе - значна орієнтованість на особистісну незалежність, не значна - на приналежність зовнішнім інститутам і авторитетам;

6) менша прихильність до порядку - порядку взагалі, зокрема соціального порядку, менш педантичного, увічливого;

7) здатність до емпатії - чуттєвість і схильність адекватніше висловлювати судження про людей;

8) відчуття гумору - здатність посміятися не тільки над іншими, а й над собою;

9) вподобання свободи й демократії - не має великого значення суспільна ієрархія [53].
Торкаючись проблеми толерантності та багатокультурності, О.О. Леонтьев зазначає, що різні форми неприйняття людей різного етнічного походження, які розмовляють іншою мовою, так звані ксенофобії, достатньо широко розповсюджені. Між тим, зауважує вчений, володіння мовою й культурою іншого народу, здібність або принаймні готовність подивитися на світ його очима є взагалі ознакою культурної людини. Багатонаціональність і полікультурність він називає багатством країни та відносить їх до факторів національної безпеки [24]. Ідея окремішності, природженої переваги над іншими народами, зауважує О.О. Леонтьев, була в основі ідеології німецького нацизму. Саме ця ідея окремішності породила поширену міфологему про споконвічну протиставленість «Заходу» і «Сходу». Проте повага до іншого народу, готовність зрозуміти й навіть прийняти його традиції та цінності зовсім не означає відмову від своїх власних традицій i цінностей, підміни їх усередненим уявленням про «західну культуру» - саме усередненим, оскільки саме національно-ментальні особливості француза й американця, англійця й італійця, грека й ізраїльтянина виявляються в даному разі винесеними «за дужки» [там само].

Що розуміє О.О. Леонтьев під загальнолюдськими цінностями в контексті толерантності? На його думку, це ті цінності, які дозволяють носіям різних національних культур, різних релігій та ідеологій знайти «спільну мову», які допомагають людям незалежно від їхнього походження, а також від їхньої самоідентифікації з тією чи тією культурою ставити загальні цілі й забезпечувати їх спільне досягнення, вирішувати наднаціональні, часом і глобальні проблеми таким чином, щоб це рішення було оптимальним для всіх. Це ті цінності, які уможливлюють баланс інтересів особистості, народу й людства, врешті-решт - їхнє виживання та поступальний розвиток у суспільстві.

О.О. Леонтьев дає суто психологічне трактування толерантності, виходячи з відповіді на риторичне запитання (одночасно вважаючи його постановку апріорі глибоко помилковим): чи $є$ у людей різних національностей якісь особливості національної свідомості, національної психології, які вигідно відрізняються від інших народів? У окремого народу, зазначає вчений, як і у всіх народів, сформувалося своє бачення світу, яке не можна назвати правильним або неправильним, хорошим або поганим, а тим більше протиставляти баченню світу іншими народами. Будь-яка нація, підсумовує науковець, не гірша і не краща від інших, вона не 
особлива, обрана нація: обраних націй немає взагалі. Чим раніше ми зрозуміємо це, що будь-яка конкретна нація «не пуп землі», а необхідна, але не виключна частина світового порядку, всесвітньої культурної й духовної єдності та всесвітньо-історичного процесу, тим краще буде для кожного $з$ нас самих і для всього світу [24].

О.О. Леонтьев пов'язує толерантність 3 «нормальною самосвідомістю громадянина» як єдністю трьох початків, трьох компонентів: 1) відчуття приналежності до свого етносу, свого народу, незалежно від національності громадян держави, любов і повага до своїх національних традицій та історії свого народу, намагання володіти своєю національною мовою й культурою; 2) відчуття приналежності до багатонаціонального суспільства (якщо воно $є$ таким), патріотизм, неодмінно поєднаний $з$ відмовою від національного марнославства, від уявлень про свою етнічну винятковість і про те, що інші народи, які живуть поруч, чимось неповноцінні порівняно 3 «моїм» народом; 3) відчуття відповідальності не тільки за долі свого народу й своєї багатонаціональної країни (якщо вона $є$ такою), а й усього світу [24].

У будь-якого народу, в будь-якому демократичному суспільстві представлені різні політичні й ідеологічні позиції, зазначає науковець. Всі вони мають право на існування, але за однієї неодмінної умови: якщо вони не мають деструктивного характеру, якщо вони не обмежують ні інтересів окремої людини, ні інтересів суспільства загалом, якщо вони не спрямовані на руйнування структури країни. Фанатичний націоналізм як прояв інтолерантності деструктивний вже тим, зауважує цей видатний психолог, що він насильно підкоряе особистість «надуманим» інтересам етносу. Значення терміну «надуманий» він пояснює як такий, який найчастіше пов'язується окремими лідерами в їх власних, аж ніяк не національних інтересах [там само].

3 еволюційних позицій до тлумачення поняття толерантності підходить О.Г. Асмолов, запевнюючи, що й людство, й наукове мислення неминуче прийдуть до відкриття, що не тільки конфлікт $\epsilon$ універсальною рушійною силою еволюції, не тільки боротьба за існування виступає як монопольна сила відмирання старих і появи нових видів на нашій планеті. Скільки б докладно не намагалися перетворити конфлікт на «перпетуум мобіле» біологічної еволюції, на антагонізм як джерело динаміки соціально-економічної істоpiï або на боротьбу між свідомим і несвідомим в індивідуальному розвитку особистості Ч. Дарвін, К. Маркс, 3. Фройд - це тільки один, як переко- нує О.Г. Асмолов, із факторів розвитку як природи, так і суспільства та особистості. Поряд 3 конфліктом, зазначає він, вчені з різних галузей знань починають розрізняти багаточисельні феномени симбіозу несхожих один на одного видів, етносів, конфесій, партій і особистостей. Якби не існувало толерантності як універсальної норми співіснування різних форм еволючійного розвитку, то хвилі агресії, конфліктів, нетерпимості, фанатизму, геноциду, ксенофобії, етнофобії, людинофобії давно б стерли будь-які прояви різноманіття на Землі, а відтак загальна гомогенність, однорідність, тоталітарність, сірість, нерухомість запанувала б у світі [3].

Намагаючись «...передати широкий спектр прояву різноманіття, його еволюційного смислу в суперечливому процесі розвитку», вчений абсолютно обгрунтовано піднімає питання цивілізаційного характеру, зазначаючи про конфлікт, боротьбу, руйнування, вічний бій, киплячий від обурення розум «немало пісень складено». А про толерантність гімнів майже не зустрічається. На це висловлювання О.Г. Асмолова дитячий письменник Б.В. Заходер відповів так: «Ви не зовсім праві», запропонувавши йому два гімна про могутність толерантності та різноманіття. Один 3 віршів цього воістину народного письменника цей науковець назвав «Чуття толерантності». Подаємо кілька рядків з одного із віршів Б.В. Заходера «Про всіх на світі»:

«И если мы с кем-то

Не очень дружны,

Мы все-таки очень

Друг другу нужны!

А если нам кто-нибудь

Лишним покажется

То это, конечно

Ошибкой окажется!»

О. Асмолов зазначає, що під час зіткнення стилів мислення, різних логік цивілізацій нам 3 вами необхідно чітко усвідомити: «Справа передусім у глибинних геополітичних і психологічних стилях бачення світу. I зіткнення саме цих стилів відбувається сьогодні» [3]. Психолог переконує: «...я повинен, якщо я стою на позиціях толерантності, здійснити неможливе. Я повинен встати на позицію медіатора, посередника. Толерантність передбачає створення унікального інституту медіаторів, або посередників, які мають не просто спробувати знищити чи елімінувати фундаменталізм, а пробувати в нелюдських світах людське. Завдання програми толерантності не карати, а «...допомогти тим, хто сьогодні діє 
за формулою «жага крові», допомогти тим, хто сьогодні в буквальному смислі вражений фундаменталістським стилем мислення, стати іншими й показати, що може бути співіснування людей 3 різними поглядами, носіями різних культур. Що ж таке толерантність? Коли ви зустрічаєте іншого, ви не зводите його до загального знаменника, а визначаєте цінність інакшості» [3, с. 315]. Спробувати зробити, «побудувати» людину під себе, або ще гірше - «виструнчити» «вибудувати» iï, $\epsilon$ невірним шляхом, зауважує психолог. Проте $\epsilon$ інший, пропонований ним, шлях: «... здивуватися і зрозуміти, що інакшість кожного з нас, можливість інших логік, інших дій - це багатство людства, яким ми володіємо». Толерантність, як підсумовує цей видатний психолог, - це «ремесло» i «найтяжча праця», «право іншого на варіанти», «дійсний мультикультуралізм, полікультурність як джерело руху в цьому світі» [там само].

Залежно від науково-галузевого контексту толерантність наповнюється тим чи іншим специфічним смислом за збереження загального змісту поняття толерантності й різних смислових, зумовлених національними особливостями, нюансів.

У тлумачних та інших словниках, а також у науковій аналітичній інформації феномен «толерантність» узагальнюється в багатьох найрізноманітніших значеннях і домінантних смислах, що багатогранно відображають різні аспекти нашої дійсності, а саме :

- складний формат міждисииплінарного знання [30] - методологічний аспект;

- моральна якість [12, 28]; результат дії багатьох сил, що діють в одному спрямуванні (темперамент, атмосфера в родині, вихованні, досвід, соціальні й культурні чинники) [53] філософський аспект;

- характеристика фізіологічної, психологічної і соціальної стійкості людини до різних впливів [40]; життєвий принщип, який сприяе виживанню людини в сучасній цивілізації $[4,10,11,31$, 49] - етичний аспект;

- «благо в собі» [33] - релігійно-етичний аспект;

- форма поведінки і спілкування з іншими [36] - суспільний аспект;

- цінність сучасного суспільства; норма цивілізованого компромісу між конкуруючими культурами; готовність до прийняття інших логік і поглядів; умова збереження різноманіття - своєрідного історичного права на відмінність, несхожість, інакшість [5] - суспільно-політичний аспект;
- важливий елемент культури спілкування, ключовий моральний приниип громадського суспільства [51] - культурологічний аспект;

- сочіальна норма, що визначає стійкість до конфліктів у поліетнічному міжкультурному суспільстві [4, с. 7]; соиіальний регулятив [35] інструментальна цінність, обмежник прояву інтолерантності (агресії), мовний фільтр, який накладає певні обмеження на спілкування, поведінку, можливість негативного відношення один до одного [52, с. 103-104] - соціальний аспект;

- комунікативна норма мовленнєвого спілкування, персональна характеристика особистості, важливий параметр мовленнєвої поведінки [32] - соціально-психологічний аспект;

- сочіально значуща характеристика - особливий позитивний спосіб прийняття відмінностей, який виключає розвиток конфронтації і ксенофобії [46] - соціально-перцептивний аспект;

- особливість особистості, яку можна розвивати і формувати [40] - психолого-педагогічний аспект;

- комунікативна стратегія [3] - комунікативний аспект;

- показник позитивних міжособистісних взаємовідносин [41] - інтеракційний аспект;

- професійно-важлива якість, один $з$ аспектів комунікативної компетентності [2] - професійний аспект.

Інші наукові уявлення, що узагальнені в значеннях та стосуються вираження толерантності в особистості індивіда, репрезентовано в психологічному аспекті, зокрема:

- поведінка [16;29];

- здібність, відномення (ставлення), характеристика поведінки, стиль поведінки, риса характеру [28];

- чуйність у спілкуванні; готовність визнавати не тільки свої помилки, а й правоту іншого; уміння терпимо відноситися до чого-небуть, терпіти щзось [26];

- людська властивість [17; 25, 26; 47];

- свідоме рімення [7];

- спосіб поведінки [34];

- прийняте

умонастрої [46];

- «погляд на світ без стійких негативних емочій і оцінок» [42, с. 5-6];

- «один із типів мовленнєвої

поведінки» $[14$, с. 4];

- настановлення [9; 18; 43];

- готовність [54];

- моральна якість [15]; 
- особистісна свідомість, особистісна риса [45];

- характеристика особистості [19;21;38];

- здібність визначати різницю $i$ здібність поважати інших [48: 411]; психологічний процес сприйняття іншого: визначати і розуміти та оцінювати і поважати [33];

- конщепт мовної картини світу, що формується, з властивою йому національною специфікою [27];

- параметр вивчення мовленнєвої поведінки мовної особистості, комунікативна норма в міжособистісному спілкуванні [32];

- правильна кооперативна мовленнєва поведінка [23];

- індиферентність, емпатія, повага, ознака гідності, терпіння [56];

- психологічна характеристика, особливо важлива під час дослідження міжгрупової взаємодії і трансформацій етнічної ідентичності; стійка особистісна риса [39];

- інтегральна характеристика індивіда - здатність в проблемних і кризисних ситуаціях активно взаємодіяти із зовнішнім середовищем з метою поновлення своєї нервово-психічної рівноваги, успішної адаптації, недопущення конфронтації і розвитку позитивних взаємовідносин 3 собою і з оточуючим світом [40];

- багатомірна характеристика, що має складну психоментальну структуру: мотиваційноціннісну, когнітивну, емоційну-вольову, поведінкову компоненту $[6 ; 20]$;

- система иіннісно-смислових настановлень, способів установлення зв'язків людини із світом [22];

- спосіб поведінки; активна позииія суб 'єкта, за якої він не просто констатує виниклу суперечку між різними моделями поведінки (і змиряється 3 нею), але й намагається зрозуміти суть цих відмінностей, осмислити їх, знайти компромісний варіант поведінки, заснований на визнанні рівності сторін, які беруть участь [50];

- терпіння, терпимість, адаптація, як пристосування людини до чогось, стійкість, витривалість (до стресу, до конфлікту та ін.), допущення, дозвіл (різних позицій, цінностей, ідеалів); прийняття іншого; намагання досягти розуміння 3 іншими, узгодити різні установки, мотиви, орі- єнтації; не вдаючись до насилля та придушення людської гідності [8];

- психічна стійкість особистості - здатність індивіда протистояти зовнішнім впливам і самостійно, з високою швидкодією повертатися в стан психічної рівноваги [44];

- внутрішньо напружена категорія - боротьба між прихильністю до власних поглядів і визнанням позицій, а також переконань інших [33; 40].

Висновки. Різноаспектний огляд і системний аналіз наукових джерел стосовно функціональнозмістового поля феномену «толерантність» у людиномірному та суто психологічному аспекті дав змогу з'ясувати, що дослідники пропонують вкрай різноманітні й навіть відверто суперечливі визначення толерантності. 3 огляду на це можна констатувати відсутність єдиного підходу до експлікації цього феномену, яка б відображала його багатогранність, функціональну багатомірність і багатовимірність. Проте в представлених визначеннях і наявних у науці підходах до толерантності можна знайти певні спільні тенденції та закономірності, які виокремлюються під час аналізу трактовок цього міждисциплінарного явища.

Наукові формулювання, в яких розкривається зміст толерантності, презентовані в кількох аспектах, зокрема: філософському, соціально-політичному, суспільно-гендерному, міждержавному, етнічному, правовому, релігійному, культурологічному, комунікаційному тощо.

Найбільш рельєфно і полівекторно толерантність представлена в психологічному аспекті: від означень цього феномену як способу поведінки та здібності до процесу, дій, свідомості, настановлень, готовності, позиції, цінності й особистості з iї необмеженими психологічними проявами у міжлюдських відносинах.

Психологічний смисл толерантності найповніше відображений у таких значеннях і смислах: набута стійкість, стійкість до невизначеності, етнічна стійкість, межа стійкості (витривалості) людини, стійкість до стресу, стійкість до конфлікту, стійкість до поведінкових відхилень.

Перспективи подальших досліджень пов'язуємо з системним аналізом різних видів толерантності, характерних для полікультурного світу.

\section{Список літератури:}

1. Абдулатипов Р.Г. Этнополитология. учебное пособие для студентов высших учебных заведений. Санкт-Петербург : Питер, 2004. С. 182.

2. Акимова М.К., Галстян О.А. Толерантность как компонент коммуникативной компетентности педагогов. Психологические исследования: электронный научный журнал. 2010. № 3(11). URL: http://psystudy.ru/index.php/num/2010n3-11/322-akimova-galstyan11.html. 
3. Асмолов А.Г. Формирование установок толерантного сознания: что могут СМИ? Библиотека. Век толерантности. 2003. № 5. URL: http://www.tolerance.ru/Vek-Tol.php.

4. Асмолов А.Г. Толерантность: от утопии к реальности. На пути к толерантному сознанию. Москва : Смысл, 2000. с. 4-7.

5. Асмолов А.Г., Солдатова Г.У., Шайгерова, Л.А. О Смыслах понятия «толерантность». Библиотека. Век толерантности. 2003. № 1-2. URL: http://www.tolerance.ru/Vek-Tol.php.

6. Асташова Н.А. Проблема воспитания толерантности в системе образовательных учреждений. Толерантное сознание и формирование толерантных отношений (теория и практика): сб. науч.-методических статей. Москва : Изд-во МПСИ; Воронеж : МОДЭК, 2003. 368 с.

7. Балцевич В.А., Балцевич С.Я. Толерантность. Энщиклопедия соииологии. 2003.

8. Безюлева Г.В., Шеламова Г.М. Толерантность: взгляд, поиск, решение. Москва : Вербум, 2003. 168 с.

9. Бойко В.В. Энергия эмоций в общении. Москва : Информ.-издат. дом «Филинъ», 1996. 472 с.

10. Бондырева С.К., Колесов Д.В. Толерантность. Воронеж : НПО «Модэк», 2003. 240 с.

11. Валитова Р.Р. Толерантность как этическая проблема : Автореф. дмсс. к.ф.н.-М., 1997. 20 с.

12. Васильева А.Б. (Ред.). Философский энциклопедический словарь. (2-е изд.). Москва : Инфра-М, 2011. 576 с.

13. Википедия. Свободная енциклопедия URL: https://ru.wikipedia.org/wiki/Толерантность_(социология).

14. Воронцова Т.A. Типология речевого поведения (коммуникативно-прагматический аспект). Cuadernos de Rusística Española. 2009. № 5. C. 21-31.

15. Гусейнова А.А., И.С. Кон (Ред.). Словарь по этике. Москва : Политиздат, 1989. 345 с.

16. Евгеньева А.П., (Ред.). Словарь русского языка: в 4-х т. РАН, Ин-т лингвистич. исследований; Москва : Полиграф ресурсы, 1999.

17. Зенович Е.С. (Авт.-сост.). Словарь иностранных слов и выражений. Москва : Олимп, ООО «Фирма «Издательство АСТ》, 1998. 477 с.

18. Ильин Е.П. Психология общения и межличностных отношений. Санкт-Петербург : Питер, 2010. $576 \mathrm{c}$.

19. Капустина Н.Г. Психологические особенности формирования толерантности в структуре мировоззрения на ранних этапах онтогенеза. Шадринск : Шадринский Дом печати, 2008. 227 с.

20. Клепцова Е.Ю. Терпимое отношение к ребенку: психологическое содержание, диагностика, коррекция. Москва: Академический проект, 2005. 192 с.

21. Костюшина Е.В. Толерантность как характеристика самоактуализирующейся личности. В кн.: Материалы VIII Всероссийской научно-практической Internet-конференции «Преподаватель высшей школы: традиции, проблемы, перспективы». Тамбов : Тамбовский государственный институт им. Г. Р. Державина, 2017.

22. Лабунская В. Социально-психологические причины интолерантного общения. Библиотека. Век толерантности. 2003. 3-4. URL: http://www.tolerance.ru/Vek-Tol.php

23. Лекция 59-60. Языковая толерантность и языковая агрессия (н.д.). URL: https://studopedia.su/10_126724_lektsiya---yazikovaya-tolerantnost-i-yazikovaya-agressiya.html

24. Леонтьев А.А. Россия: многокультурность и толерантность. Библиотека. Век толерантности. 2003. 1-2. URL: http://www.tolerance.ru/Vek-Tol.php.

25. Макаров Ю.А. Внешние и внутренние источники толерантности. Вестник СПбГУ, 4(12), 2011. C. $117-129$

26. Макарьева А.А., Блинов А.В. Толерантность и терпимость: соотношения понятий. Вестник ГвГУ. 2015. № 2. C. 128-132.

27. Малафеев А.Ю., Орехова Е.А. Толерантность по-русски и по-английски: корпусное исследование. В. Селегей (Ред.), Компьютерная лингвистика и интеллектуальные технологии: по материалам международной конференции «Диалог 2017» (г. Москва, 31 мая - 3 июня 2017г.). 16 (23): В 2 т. Москва: Издательство «РГГУ», 2017.

28. Малый энциклопедический словарь Брокгауза и Ефрона. (1907-1909). Толерантность. (в 4 т.). Санкт-Петербург.

29. Марголина Т. Толерантность — это не попустительство пороку. Толерантность — это великодушие! Известия. 2009. URL: https://iz.ru/news/345801

30. Мацковский М.С. Толерантность как объект социологического исследования. Век толерантности. 2003, 4. URL: http://www.tolerance.ru/VT-3-4-toler-kak.php?PrPage=VT.

31. Медведев Н.П. Толерантность как основа социальной безопасности: монография. Ставрополь : Изд-во Ставропольского государственного университета, 2002. 286 с.

32. Никитина И.С. Вербализация толерантности в межличностном политическом общении. Исследования языка и современное гуманитарное знание. 2020. Т. 2, № 2. С. 63-71. 
33. Николсон П.П. Толерантность как моральный идеал. Вестник Уральского межрегионального института общественных наук. 2001. № 1. с. 129-146.

34. Прохоров А.М. (Гл. ред). Толерантность. Большой Энциклопедический словарь, (2-е изд., перераб. и доп.). Санкт-Петербург : Норинт, 2004. 1456 с.

35. Романова Т.В. Информационный обзор: категории толерантность/политкорректность как объект лингвистического осмысления. Вопросы психолингвистики. 2018. № 4 (38). 204-219.

36. Сейдикенова А.С., Минаева Н. «Способы лексической репрезентации концепта «толерантность» в английской и казахской культуре». Коллективная монография «Между словами, между мирами» Варминско-Мазурском Университете, г. Ольштн (Польша), 2017 г. с. 51-63.

37. Семашко М.А. Развитие термина «толерантность» в гуманитарных науках. Электронный научнопедагогический журнал, 2007.

38. Селюкова Е.А., Фокина М.Н. Воспитание толерантных взаимоотношений в школе. Актуальные вопросы современной педагогики. Материалы III Международной научной конференции (20-23 марта 2013 г.). Уфа: Лето, 2013. с. 103-105.

39. Солдатова Г.У. Толерантность и интолерантность - две грани межэтнического взаимодействия. Библиотека. Век толерантности. 2003 a. 1-2. URL: http://www.tolerance.ru/Vek-Tol.php

40. Солдатова Г.У. Практическая психология толерантности, или как сделать так, чтобы зазвучали лучшие струны человеческой души? Библиотека. Век толерантности. 2003 b. 6. URL: http://www.tolerance.ru/Vek-Tol.php

41. Спицына О.А. К вопросу о структуре межличностной толерантности. В.Н. Малиновская (ред.). Психолого-педагогические аспекты проблемы качества образования в системе общей и профессиональной школы: сборник научных материалов четвертой окружной научно-практической конференции «Знаменские чтения»: в 2 ч. Ч. 1. Сургут : Наука и педагогика, 2005. с. 213-220.

42. Стернин И.А., Шилихина К.М. Коммуникативные аспекты толерантности. Монографія. Воронеж. 2000. $110 \mathrm{c}$.

43. Тишков В.А. О толерантности. Этнополитический вестник. 1995. № 5(11). с. 24.

44. Трифонов Е.В. Психофизиология человека. Толковый русско-англо-русский словарь, 2001.

45. Тренгулова, С.Ф. (н.д.). Формирование толерантности студентов в условиях поликультурного мира. URL: https://kazgik.ru/kcontent/main/conference_competition/Problemy\%20i\%20perspektivy/2/2_10.pdf.

46. Уолцер, М.О. О терпимости. И. Мюрнберг (Перевод с англ. яз.). Москва : Идея-Пресс, Дом интеллектуальной книги, 2000.

47. Ушаков Д.Н. (Ред.). (1935-1940). Толковый словарь русского языка. Толерантность. URL: https://ushakovdictionary.ru/word.php?wordid=77190.

48. Хокинс Дж. М., Делаханти Э. Новый словарь английского языка Oxford. Москва : ООО «Астрель»: ООО «Издательство АСТ», 2002. 480 с.

49. Шалин В.В. Толерантность (культурная норма и политическая необходимость). Краснодар : Периодика Кубани, 2000. 256 с.

50. Шкуратова И. Когнитивная сложность как основа толерантного мышления. Библиотека. Век толерантности. 2003. № 5. URL: http://www.tolerance.ru/Vek-Tol.php.

51. Электронная библиотека «ИФ РАН» «Новая философская энциклопедия» ТОЛЕРАНТНОСТЬ (н.д.). URL: https://iphlib.ru/library/collection/newphilenc/document/HASHbb6bc2e9803479862096bb.

52. Яворська Г.Х., Ларіна Е.В. Мовна толерантність у контексті соціально-гуманітарних наук. Науковий вісник Міжнародного гуманітарного університету. 2016. 20(1), (Ч. 1). 103-106. URL: http://vestnik-philology.mgu.od.ua/archive/v20/part_1/31.pdf

53. Allport G.W. The nature of prejudice. Cambridge, MA: Perseus Books, 1954.

54. Concise Oxford Dictionaru of Current English. (н.д.) URL: http://www.cap.ru/home/76/gorono/2005/ school6/tolerant_opredelenie.htm.

55. Karlheinz, B. \& Stiegeler M. de L. Wörterbuch der Logotherapie und Existenzanalyse von Viktor Emil Frankl. Böhlau, 2008. c. 471-472.

56. Wierlacher A., Bogner A. (eds.), Handbuch interkulturelle Germanistik. Metzler Verlag, 2003. pp. $388-395$ (Part of book).

\section{Kalmykov H.V., Mysan I.V., Rudkivska N.L. FUNCTIONAL-SEMANTIC FIELD OF VALUES OF THE PHENOMENON "TOLERANCE" IN THE HUMANIZING SCIENCES}

The article reveals different approaches to the interpretation of tolerance, substantiates the need to consider in functional and semantic field of values of the phenomenon tolerance of the new values associated with the active acceptance by a man of the surrounding reality, with a differentiated, but one that doesn't contradict to 
the norm of law, tolerant attitude to others. Tolerance as a scientific issue, world strategy and a key concept in matters of peace is relevant in view of its importance for social life in societies.

It represents the little-known opinions of authoritative psychologists on the essence of this scientific category; shows scientific approaches to its interpretation and systematization of psychological explication of tolerance.

The main material of the article presents the results of a systematic analysis of the modern literary sources, in particular, is indicated the need to understand the meanings of tolerance to transform it into a value and norm of relationships, which is primarily the work of scientists.

The article is also devoted to: highlighting of various aspects in the interpretation of tolerance: philosophical, methodological, ethical, public, socio-political, social, culturological, socio-psychological, socio-perceptual, psycho-pedagogical, professional; psychological consideration of tolerance as behavior, ability, properties, conscious decision, attitude, character traits, moral quality, and many other values.

Systematic review and systematic analysis of scientific sources made it possible to state the lack of a unified approach to the explication of this phenomenon, which would reflect its versatility, multidimensionality and multimeasuring. However, in the presented definitions and available in science approaches to tolerance, we can find certain common trends and patterns that are identified in the analysis of interpretations of this phenomenon.

Key words: tolerance, psychological meanings, functional-semantic field, meanings. 